\title{
Metabolic response of oligotrophic plankton communities to deep water nutrient enrichment
}

\author{
Patricia M. McAndrew ${ }^{1, *}$, Karin M. Björkman ${ }^{1}$, Matthew J. Church ${ }^{1}$, Paul J. Morris ${ }^{1,3}$, \\ Nicholas Jachowski ${ }^{1,4}$, Peter J. le B. Williams ${ }^{2}$, David M. Karl ${ }^{1}$ \\ ${ }^{1}$ Department of Oceanography, University of Hawaii, 1000 Pope Road, Honolulu, Hawaii 96822, USA \\ ${ }^{2}$ School of Ocean Sciences, University of Wales, Bangor, Menai Bridge, Anglesey LL59 5EY, UK
}

${ }^{3}$ Present address: National Oceanography Centre, University of Southampton, European Way, Southampton SO14 3ZH, UK

${ }^{4}$ Present address: Stanford University, Palo Alto, California 94305, USA

\begin{abstract}
Studies on upper ocean plankton production and respiration in oligotrophic ecosystems are taken to imply that these regions are net heterotrophic (i.e. gross primary production [GPP] < respiration $[R])$. In this study we examined the hypothesis that the regularly observed state of net heterotrophy in the oligotrophic North Pacific Ocean may be interrupted by periodic bursts of net autotrophy when GPP becomes decoupled from R. To examine this hypothesis, we conducted a series of nutrient addition experiments in the oligotrophic North Pacific Subtropical Gyre (NPSG) in which nutrient-replete deep seawater was mixed with nutrient-depleted mixed-layer water. We monitored time-dependent changes in rates of GPP and R as well as dynamics of chlorophyll and nutrient concentrations. Our results consistently demonstrated that following the addition of nutrients: (1) phytoplankton biomass ( $\mathrm{chl}$ a) and primary production increase; (2) the photoautotrophic plankton assemblage shifts from small $(<2 \mu \mathrm{m}$ diameter) to large $(>10 \mu \mathrm{m}$ diameter $)$, chl $c$-containing and Siutilizing cells; and (3) community metabolism shifts from near balance, or slightly net heterotrophic, to demonstrably net autotrophic metabolism. These results suggest that nutrient availability partly regulates plankton community structure and dynamics, and could serve as a mechanism to temporally and spatially decouple GPP and R in oligotrophic open ocean ecosystems.
\end{abstract}

KEY WORDS: Metabolic balance - Net community production · Respiration · Nutrient addition · Oligotrophic $\cdot$ North Pacific Ocean $\cdot$ Stn ALOHA

Resale or republication not permitted without written consent of the publisher

\section{INTRODUCTION}

Understanding the global carbon cycle is a major contemporary challenge in Earth sciences. Oceanic gross primary production (GPP) and respiration (R) partly regulate global metabolism, but our knowledge of these processes and the biologically mediated reactions controlling them remains incomplete. In 1987, Smith \& Mackenzie compiled estimates of global ocean GPP and R and concluded that while on average the global ocean acts as a sink for carbon dioxide $\left(\mathrm{CO}_{2}\right)$, ocean metabolism was a net source of $\mathrm{CO}_{2}$ (net heterotrophic, GPP $<$ R) to the atmosphere. However, they noted that net heterotrophy occurred predominantly in nearshore environments, fueled largely by terrigenous input of organic carbon, and that open ocean regions likely sustained marginal net autotrophy (GPP > R) to balance the nearshore heterotrophy. Under steady-state conditions, wherein changes in biomass are minimal, characteristic features of net autotrophic marine ecosystems include a net flux of oxygen $\left(\mathrm{O}_{2}\right)$ to the atmosphere, accumulation of organic carbon in the euphotic zone and/or net export of organic carbon (C) to subeuphotic zone depths.

More recently, several investigators concluded that oligotrophic open ocean ecosystems maintain a state of 
net heterotrophy (del Giorgio et al. 1997, Duarte \& Agusti 1998, del Giorgio \& Duarte 2002). Based on compilations of measurements of net primary production (NPP) and bacterial respiration (R), del Giorgio et al. (1997) found that NPP and R varied systematically across trophic gradients, with $\mathrm{R}$ tending to exceed NPP in unproductive ecosystems, defined as those systems where NPP $\leq 6$ to $10 \mathrm{mmol} \mathrm{C} \mathrm{m}^{-3} \mathrm{~d}^{-1}$. Ecosystems with NPP below this threshold would include most of the world's open ocean habitats (Behrenfeld et al. 2002). Duarte \& Agusti (1998) also concluded that unproductive aquatic ecosystems have a disproportionately higher $\mathrm{R}$ relative to GPP compared with productive ecosystems, identifying the former as net sinks for organic $\mathrm{C}$ and $\mathrm{O}_{2}$ and net sources of $\mathrm{CO}_{2}$.

The conclusion that open ocean ecosystems are net heterotrophic generally contradicts various lines of geochemical evidence that suggest oligotrophic ocean ecosystems are net autotrophic (Emerson et al. 1995, 2002, Abell et al. 2000, Najjar \& Keeling 2000, Smith et al. 2002, Juranek \& Quay 2005). The maintenance of net heterotrophy in oligotrophic areas requires supplies of allochthonous organic material to physically isolated ecosystems (Williams \& Bowers 1999). Geographic location likely determines the importance of allochthonous versus locally produced organic matter (Serret et al. 2002). Advection could supply organic material; however, dissolved organic carbon (DOC) gradients are generally in the opposite direction (Hansell et al. 1997, Abell et al. 2000, Church et al. 2002). Dachs et al. (2005) determined that aeolian inputs of terrestrially and anthropogenically derived material could provide organic matter to the oceans; however, the remoteness of many oligotrophic areassuch as the center of the North Pacific Subtropical Gyre (NPSG) - from continental land masses make aeolian input an unlikely source. Seasonal uncoupling of respiration from photosynthesis has also been proposed as an explanation for apparent net heterotrophy (Sherr \& Sherr 1996, Serret et al. 1999, Aristegui \& Harrison 2002), but a recent study in the NPSG by Williams et al. (2004) failed to provide evidence for seasonality in net autotrophy.

Another explanation for the observed imbalance in metabolism is that it arose from inaccuracies of interpretation in the methods for measuring photosynthesis and respiration. This was discussed by Williams et al. (2004), who rejected the explanation on the grounds that the oxygen technique overcame the accuracy problem: the primary measurement is net $\mathrm{O}_{2}$ production, which is the property required. Although this argument is most probably sound for a sample in the bottle, it does not take into consideration the possibility that an incubated sample may not have been exposed to the appropriate physiological conditions. The water column is turbulent, resulting in the phytoplankton being exposed to a variable light field, which in situ incubations are unable to mimic. Marra (1978) showed that by subjecting plankton samples to a variable light field, up to $87 \%$ increases in photosynthesis could result. Such a phenomenon could resolve the mass balance problem, but would still leave the photosynthetic rates through much of the water column below the threshold $\left(1.1 \mathrm{mmol} \mathrm{O}_{2} \mathrm{~m}^{-3} \mathrm{~d}^{-1}\right)$ for net production proposed by Duarte \& Agusti (1998) for the open ocean. Thus, Stn ALOHA, the study site of the Hawaii Ocean Time-series (HOT) located in the central NPSG, would stand in contravention to the 'threshold model.'

One of the untested assumptions necessary for deriving estimates of net ecosystem metabolism based on short-term (hours to days) in vitro incubation experiments rests on whether the time and space scaling of such short-term incubations are appropriate for ecosystem extrapolation. Compared to biological incubation measurements, geochemical tracers generally integrate over larger temporal and spatial scales, thereby eliminating high frequency (hourly to daily) variability in planktonic respiration and production. Proper time-space scale assessment is critical for open ocean ecosystems, because microorganism response times are short (hourly to daily) and particulate organic matter (POM) pool residence times are generally less than 1 mo. Aperiodic increases in $\mathrm{O}_{2}$ saturation, with durations of a few days to $1 \mathrm{wk}$ and variable frequencies of weeks to months, have been observed in open ocean surface waters at Stn ALOHA (Emerson et al. 2002). These phenomena suggest bursts of net community production (NCP) when GPP - R > 0. In a statistical sense, such events would not be properly represented in $1 \mathrm{~d}$ incubation experiments.

This concept was the motivation for the present study. We aimed to explore one mechanism by which bursts of net autotrophic production could occur. We conducted a series of field incubation experiments wherein variable proportions of nutrient-replete deep seawater (DSW) were added to oligotrophic mixedlayer seawater (MLSW) and sampled periodically during 5 to $7 \mathrm{~d}$ incubations. Nutrient enrichment by addition of deep water initiated pulses of photosynthesis, enabling us to examine both the time scale of the response to nutrient perturbation and the time dependency of the balance of photosynthesis and respiration on short time scales. Based on results from these field experiments, we concluded that nutrient input has the potential to fundamentally alter the balance between GPP and R in the oligotrophic upper ocean, and may be one mechanism by which periodic bursts of net autotrophic metabolism occur. 


\section{MATERIALS AND METHODS}

Sites and sample collection. Five experiments were conducted at various locations in the NPSG using a common experimental design. Expts I, II and III were conducted during the Marine Oceanic Nitrogen Fixation and Global Climate component of the Biocomplexity program (Cruise MP9, July-August 2003). Expt I was conducted at $25^{\circ} 59^{\prime} \mathrm{N}, 175^{\circ} 59^{\prime} \mathrm{W}$, Expt II at $26^{\circ} 40^{\prime} \mathrm{N}$, $177^{\circ} 46^{\prime} \mathrm{W}$, and Expt III at $18^{\circ} 58^{\prime} \mathrm{N}, 154^{\circ} 50^{\prime} \mathrm{W}$ (Fig. 1). Expts IV and V were carried out at Station ALOHA $\left(22^{\circ} 45^{\prime} \mathrm{N}, 158^{\circ} 00^{\prime} \mathrm{W}\right)$, the open ocean site of the HOT program (Karl \& Lukas 1996), during July 2004 (HOT161) and November 2004 (HOT-165), respectively.

For each experiment, nutrient-replete DSW was obtained from $700 \mathrm{~m}$, chosen for its location well below the mixed layer and its inorganic macro-nutrient (nitrate $\left[\mathrm{NO}_{3}{ }^{-}\right]$, phosphate $\left[\mathrm{PO}_{4}{ }^{3-}\right]$, silicate $\mathrm{SiO}_{2}$ ) and trace-nutrient (e.g. metals and vitamins) content. Nutrient depleted, MLSW was obtained from the approximately $30 \%$ light-level (25 to $45 \mathrm{~m}$ ). DSW was added to MLSW to yield final concentrations of 5 and $10 \%$ DSW (by volume). As a point of reference, $5 \%$ DSW added approximately $1.5 \mathrm{mmol} \mathrm{m} \mathrm{m}^{-3} \mathrm{NO}_{3}^{-}$, $0.1 \mathrm{mmol} \mathrm{m}^{-3} \mathrm{PO}_{4}{ }^{3-}$ and $3 \mathrm{mmol} \mathrm{m}^{-3} \mathrm{SiO}_{2}$ to MLSW that had, on average, $<0.01 \mathrm{mmol} \mathrm{m}^{-3} \mathrm{NO}_{3}{ }^{-}, 0.05 \mathrm{mmol} \mathrm{m}^{-3}$ $\mathrm{PO}_{4}{ }^{3-}$, and $1.2 \mathrm{mmol} \mathrm{m}^{-3} \mathrm{SiO}_{2}$. Samples of MLSW without added DSW served as controls. All water was mixed into and incubated in acid-cleaned polycarbonate carboys with a total volume of approximately $25 \mathrm{dm}^{-3}$. Time zero $\left(t_{0}\right)$ samples were collected and the remaining carboys incubated in a shipboard incubator at sea surface temperature. The incubator was covered with blue plexiglass filters (\#2069, Rohm and Haas) to simulate in situ light quality and quantity at the $30 \%$ light-level. Table 1 contains a summary of locations, times and parameters measured for each experiment.

Nutrients, pigments and flow cytometry. Nitrate plus nitrite $(\mathrm{N}+\mathrm{N})$, soluble reactive phosphorus (SRP), and silicic acid $\left(\mathrm{SiO}_{2}\right)$ were measured using a Bran \& Lubbe (AA-3) continuous flow system (Armstrong et al. 1967). SRP (hereafter $\mathrm{PO}_{4}{ }^{3-}$ ) was also measured using the high-sensitivity MAGIC method, which provided more accurate and precise estimates of $\mathrm{PO}_{4}{ }^{3-}$ concentrations at $\leq 200 \mu \mathrm{mol} \mathrm{m}{ }^{-3}$ (Karl \& Tien 1992). For the chlorophyll and pigment analyses, 3 replicate $125 \mathrm{~cm}^{-3}$ samples were taken at each time point. Samples were filtered onto glass fiber filters (Whatman $\mathrm{GF} / \mathrm{F}$ ), and pigments were extracted from the filter using $100 \%$ HPLC-grade

Fig. 1. Location of Expts I to V near the Hawaiian Islands, North Pacific

Table 1. Dates, locations, experimental treatments and properties measured during this study. Date and location reflect where and when water was obtained for each experiment. Treatments are control (unamended mixed-layer) and 5 and $10 \%$ vol/vol additions of deep seawater (DSW) to mixed-layer seawater (MLSW). Parameters measured include chlorophyll (chl), radiocarbon assimilation $\left({ }^{14} \mathrm{C}\right)$, primary production using $\mathrm{O}_{2}$ light/dark bottles, phosphate $\left(\mathrm{PO}_{4}{ }^{3-}\right)$, nitrate+nitrite $(\mathrm{N}+\mathrm{N})$, silicate $\left(\mathrm{SiO}_{2}\right)$ and cell counts by flow cytometry $(\mathrm{FCM})$

\begin{tabular}{|c|c|c|c|c|c|c|c|c|c|c|c|c|c|}
\hline \multirow[t]{2}{*}{ Expt } & \multirow[t]{2}{*}{ Date } & \multirow[t]{2}{*}{ Location } & \multirow[t]{2}{*}{ Treatment } & \multicolumn{10}{|c|}{ - Parameters measured - } \\
\hline & & & & $t_{0}$ & $24 \mathrm{~h}$ & $36 \mathrm{~h}$ & $48 \mathrm{~h}$ & $60 \mathrm{~h}$ & $72 \mathrm{~h}$ & $84 \mathrm{~h}$ & $96 \mathrm{~h}$ & $120 \mathrm{~h}$ & $144 \mathrm{~h}$ \\
\hline I & $\begin{array}{l}\text { Jul } \\
2003\end{array}$ & $\begin{array}{l}25^{\circ} 59^{\prime} \mathrm{N} \\
175^{\circ} 59^{\prime} \mathrm{W}\end{array}$ & $\begin{array}{l}\text { Control } \\
5 \% \text { DSW } \\
10 \% \text { DSW }\end{array}$ & $\begin{array}{l}\mathrm{Chl}^{14}{ }^{14} \mathrm{C}_{1} \\
\mathrm{O}_{2}, \mathrm{PO}_{4}{ }^{3-}\end{array}$ & & $\mathrm{Chl}$ & & $\mathrm{Chl}$ & & $\mathrm{Chl}$ & & Chl & $\begin{array}{l}\mathrm{Chl},{ }^{14} \mathrm{C}_{1} \\
\mathrm{O}_{2}, \mathrm{PO}_{4}{ }^{3-}\end{array}$ \\
\hline II & $\begin{array}{l}\text { Jul } \\
2003\end{array}$ & $\begin{array}{l}26^{\circ} 40^{\prime} \mathrm{N} \\
177^{\circ} 46^{\prime} \mathrm{W}\end{array}$ & $\begin{array}{l}\text { Control } \\
5 \% \text { DSW } \\
10 \% \text { DSW }\end{array}$ & $\begin{array}{c}\mathrm{Chl}{ }^{14}{ }^{14}{ }_{1} \\
\mathrm{O}_{2}, \mathrm{PO}_{4}{ }^{3-} \\
\mathrm{N}+\mathrm{N}, \mathrm{SiO}_{2}\end{array}$ & & Chl & & & & & $\begin{array}{c}\mathrm{Chl},{ }^{14} \mathrm{C}_{1} \\
\mathrm{O}_{2}, \mathrm{PO}_{4}{ }^{3-} \\
\mathrm{N}+\mathrm{N}, \mathrm{SiO}_{2}\end{array}$ & & \\
\hline III & $\begin{array}{l}\text { Aug } \\
2003\end{array}$ & $\begin{array}{l}18^{\circ} 58^{\prime} \mathrm{N} \\
154^{\circ} 50^{\prime} \mathrm{W}\end{array}$ & $\begin{array}{l}\text { Control } \\
5 \% \text { DSW } \\
10 \% \text { DSW }\end{array}$ & $\begin{array}{c}\mathrm{Chl}^{14}{ }^{14} \mathrm{C}_{1} \\
\mathrm{O}_{2,} \mathrm{PO}_{4}{ }^{3-}, \\
\mathrm{FCM}^{-}\end{array}$ & Chl & & $\begin{array}{l}\text { Chl, } \\
\text { FCM }\end{array}$ & & $\begin{array}{l}\mathrm{Chl}_{\text {, }} \\
\text { FCM }\end{array}$ & & $\begin{array}{c}\mathrm{Chl}_{,}{ }^{14} \mathrm{C}_{1} \\
\mathrm{O}_{2,} \mathrm{PO}_{4}{ }^{3-}{ }^{\prime} \\
\mathrm{FCM}^{-}\end{array}$ & & \\
\hline IV & $\begin{array}{l}\text { Jul } \\
2004\end{array}$ & $\begin{array}{l}\text { Stn ALOHA } \\
22^{\circ} 45^{\prime} \mathrm{N} \\
158^{\circ} \mathrm{W}\end{array}$ & $\begin{array}{l}\text { Control } \\
5 \% \text { DSW }\end{array}$ & $\begin{array}{c}\mathrm{Chl},{ }^{14} \mathrm{C}_{1} \\
\mathrm{PO}_{4}{ }^{3-} \\
\mathrm{N}+\mathrm{N}_{1} \mathrm{SiO}_{2}\end{array}$ & $\begin{array}{c}\mathrm{Chl}, \\
\mathrm{PO}_{4}{ }^{3-} \\
\mathrm{N}+\mathrm{N}, \mathrm{SiO}_{2}\end{array}$ & $\begin{array}{c}\mathrm{Chl},{ }^{14} \mathrm{C}_{1} \\
\mathrm{Chl}, \mathrm{PO}_{4}{ }^{3-}, \\
\mathrm{N}+\mathrm{N}, \mathrm{SiO}_{2}\end{array}$ & $\begin{array}{c}\mathrm{Chl}_{1}{ }^{14} \mathrm{C}_{1} \\
\mathrm{PO}_{4}{ }^{3-} \\
\mathrm{N}+\mathrm{N},{ }^{-} \mathrm{SiO}_{2}\end{array}$ & $\begin{array}{c}\mathrm{Chl}_{1}{ }^{14} \mathrm{C}_{1} \\
\mathrm{PO}_{4}{ }^{3-} \\
\mathrm{N}+\mathrm{N},{ }^{-} \mathrm{SiO}_{2}\end{array}$ & $\begin{array}{c}\mathrm{Chl},{ }^{14} \mathrm{C}_{1} \\
\mathrm{PO}_{4}{ }^{3-} \\
\mathrm{N}+\mathrm{N}, \mathrm{SiO}_{2}\end{array}$ & & $\begin{array}{c}\mathrm{Chl}_{,}{ }^{14} \mathrm{C}_{1} \\
\mathrm{PO}_{4}{ }^{3-} \\
\mathrm{N}+\mathrm{N}, \mathrm{SiO}_{2}\end{array}$ & $\begin{array}{c}\mathrm{Chl}_{1}{ }^{14} \mathrm{C}_{1} \\
\mathrm{PO}_{4}{ }^{3-} \\
\mathrm{N}+\mathrm{N},{ }^{-} \mathrm{SiO}_{2}\end{array}$ & \\
\hline V & $\begin{array}{l}\text { Nov } \\
2004\end{array}$ & $\begin{array}{l}\text { Stn ALOHA } \\
22^{\circ} 45^{\prime} \mathrm{N} \\
158^{\circ} \mathrm{W}\end{array}$ & $\begin{array}{l}\text { Control } \\
5 \% \text { DSW }\end{array}$ & $\begin{array}{c}\mathrm{Chl}_{1}{ }^{14} \mathrm{C} \\
\mathrm{PO}_{4}{ }^{3-}\end{array}$ & & & $\begin{array}{c}\mathrm{Chl},{ }^{14} \mathrm{C} \\
\mathrm{PO}_{4}{ }^{3-}\end{array}$ & & $\begin{array}{c}\mathrm{Chl},{ }^{14} \mathrm{C} \\
\mathrm{PO}_{4}{ }^{3-}\end{array}$ & & $\mathrm{Chl},{ }^{14} \mathrm{C}$ & & \\
\hline
\end{tabular}


acetone. Chlorophyll (chl) $a, b$ and $c$ were measured after a $24 \mathrm{~h}$ extraction and again after $48 \mathrm{~h}$ of extraction on a Turner Designs TD-700 fluorometer (Strickland \& Parsons 1972, Welschmeyer 1994). Upon return to shore, chl a was also analyzed on a Turner Designs 10-AU fluorometer (Holm-Hansen et al. 1965). In the shore-based laboratory, flow cytometry measurements were analyzed on a Beckman-Coulter Altra flow cytometer (Campbell \& Vaulot 1993, Monger \& Landry 1993, Campbell et al. 1994). Chl a concentrations were best-fit to an exponential curve to determine growth rates.

Primary production. Photosynthetic primary production was measured by 2 methods: (1) $\mathrm{O}_{2}$ light/dark bottles, and (2) radiocarbon $\left(\mathrm{H}^{14} \mathrm{CO}_{3}{ }^{-}\right)$assimilation. The former provides estimates of GPP, R and NCP, whereas the latter provides a measure of carbon assimilation between GPP and NPP (Marra 2002). For $\mathrm{O}_{2}$ measurements, 6 replicates were prepared for each time point, and each replicate consisted of a $t_{0}$, a light and a dark bottle. Sub-samples were taken in precisely calibrated, ground-glass topped, borosilicate bottles with a nominal volume of $125 \mathrm{~cm}^{3}$. Light bottles were attached to a polycarbonate rack, and dark bottles were placed in opaque black bags. Both were placed in the incubator for $24 \mathrm{~h}$ before being fixed for Winkler titration (Carritt \& Carpenter 1966). After fixing reagents were added, samples were stored underwater until analysis to prevent gas exchange. The Winkler titration was performed using a computercontrolled photometric end-point detector (Williams \& Jenkinson 1982). R was calculated by subtracting the $\mathrm{O}_{2}$ concentration in the dark bottle $\left(\left[\mathrm{O}_{2}\right]_{\text {dark }}\right)$ after $24 \mathrm{~h}$ incubation from the $\mathrm{O}_{2}$ concentration in the $t_{0}$ bottle $\left(\left[\mathrm{O}_{2}\right]_{t_{0}}\right)$. NCP was calculated by subtracting $\left[\mathrm{O}_{2}\right]_{t_{0}}$ from the $\mathrm{O}_{2}$ concentration in the $\mathrm{O}_{2}$ concentration in the light bottle $\left(\left[\mathrm{O}_{2}\right]_{\text {light }}\right)$, and GPP was calculated by adding the magnitude of NCP and R. ANOVA (95\% confidence level) and Tukey's analysis with a $5 \%$ error rate were performed to determine statistical significance of results.

For the $\mathrm{C}$ assimilation incubations, $40 \mathrm{~cm}^{3}$ of sample (Expts I to III) or $500 \mathrm{~cm}^{3}$ of sample (Expts IV to V) were inoculated with $50 \mu \mathrm{Ci} \mathrm{H}^{14} \mathrm{CO}_{3}{ }^{-}$and incubated in vitro at the $30 \%$ light-level for $12 \mathrm{~h}$. Following the incubation, samples were filtered onto Whatman GF/F filters and frozen. Before analysis, samples were acidified using $2 \mathrm{~N} \mathrm{HCl}$ and vented for $24 \mathrm{~h}$ before the addition of $10 \mathrm{~cm}^{3}$ Aquasol-2 liquid scintillation cocktail. Samples were measured within $1 \mathrm{~d}$ of the addition of scintillation cocktail and again after a 1 mo period of dark storage (Letelier et al. 1996, Karl et al. 1998). The disintegration per minute (dpm) data obtained after the 1 mo storage period were used to calculate rates of carbon assimilation. ${ }^{14} \mathrm{C}$ assimilation rates were also size- fractionated into 0.2 to $2.0,2.0$ to 10.0 and $>10 \mu \mathrm{m}$ size fractions during Expt V.

\section{RESULTS \\ Expt I}

The unamended MLSW treatments showed little variance in chlorophyll (Fig. 2a,e; specific growth rate $\mu=0.20 \mathrm{~d}^{-1}$ ) or rates of GPP, NCP and R relative to $t_{0}$ throughout the course of the experiment (Fig. 3). Overall, the unamended treatments began and ended as net heterotrophic systems (no statistical difference between $t_{0}$ and final GPP, $\mathrm{p}=0.027$ ); however, the GPP:R ratio increased slightly during the experiment. The $5 \%$ DSW treatment demonstrated net increases in chlorophyll concentrations $\left(\mu=0.36 \mathrm{~d}^{-1}\right)$ and a modest drawdown in nutrients (Table 2). GPP and R increased 10- and 4-fold, respectively, during the course of the experiment, resulting in a switch from negative to positive $\mathrm{O}_{2}$ flux for the system, and the GPP:R ratio increased 3 -fold to 1.4 . The $10 \%$ DSW treatment demonstrated the most significant changes relative to the unamended treatment in response to the addition of DSW. Chl a increased 34-fold $\left(\mu=0.70 \mathrm{~d}^{-1}\right)$ and $\operatorname{chl} c$ increased 20-fold. Again, GPP and R increased 60-fold (significantly different from control, $\mathrm{p}=0.027$ ) and 5fold (not significantly different from control, $p=0.424$ ), respectively, and the GPP:R ratio increased almost 20 -fold to a value of 8.5 , switching from negative to positive $\mathrm{O}_{2}$ flux (Table 3 ). The rate of drawdown of $\mathrm{PO}_{4}{ }^{3-}$ increased with increasing $\%$ nutrient addition (Table 2).

\section{Expt II}

As in Expt I, the unamended treatment in Expt II exhibited only small changes in chl a relative to nutrient amended samples $\left(\mu=0.03 \mathrm{~d}^{-1}\right)$. NCP remained slightly positive throughout the experiment at $0.18 \mathrm{mmol} \mathrm{O}_{2} \mathrm{~m}^{-3} \mathrm{~d}^{-1}$, and the GPP:R ratio increased from 1.1 to 1.2 . The addition of $5 \%$ DSW caused increases in chl a (14-fold, $\left.\mu=0.64 \mathrm{~d}^{-1}\right)$, GPP (10-fold, $\mathrm{p}=$ $0.063)$ and $\mathrm{R}(6$-fold, $\mathrm{p}<0.0005)$. NCP remained positive throughout the experiment, and the GPP:R ratio increased from 1.1 at $t_{0}$ to 1.6 at $96 \mathrm{~h}$. The $10 \% \mathrm{DSW}$ treatment resulted in the largest response in chlorophyll (chl a increased 63-fold, $\mu=1.01 \mathrm{~d}^{-1}$, and $\operatorname{chl} C$ increased 35-fold; Fig. 2b,f), nutrient drawdown, GPP (30-fold, $\mathrm{p}=0.063)$ and $\mathrm{R}(13$-fold, $\mathrm{p}<0.0005)$. The GPP:R ratio increased from 1.1 to 2.4 , becoming increasingly net autotrophic throughout the experiment (Tables 2 \& 3). 

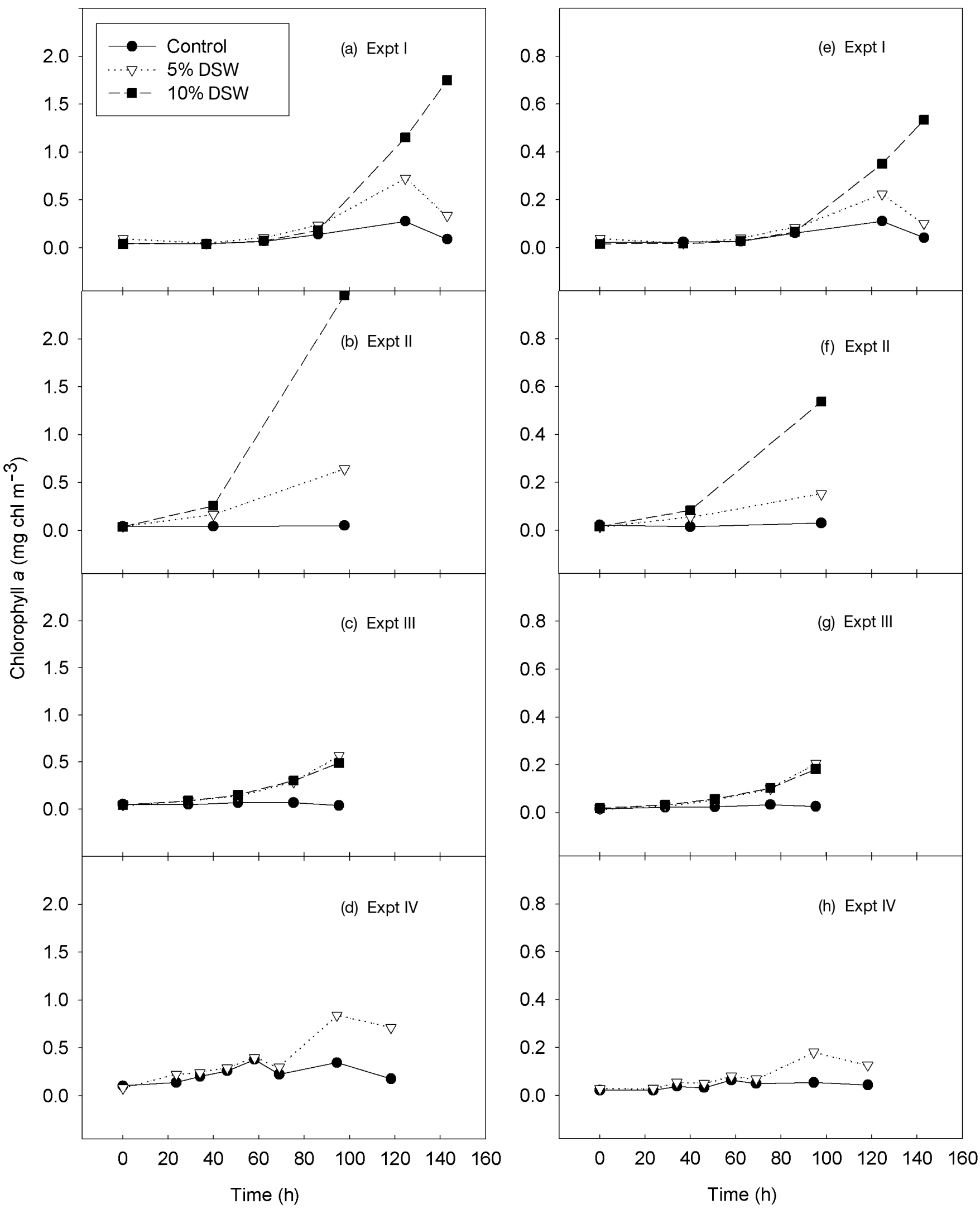

Fig. 2. (a-d) $\mathrm{Chl} a$ and $(\mathrm{e}-\mathrm{h}) \mathrm{chl} c$ Expts I to IV. Unamended control and additions of 5 and $10 \%$ deep seawater (DSW) are shown 

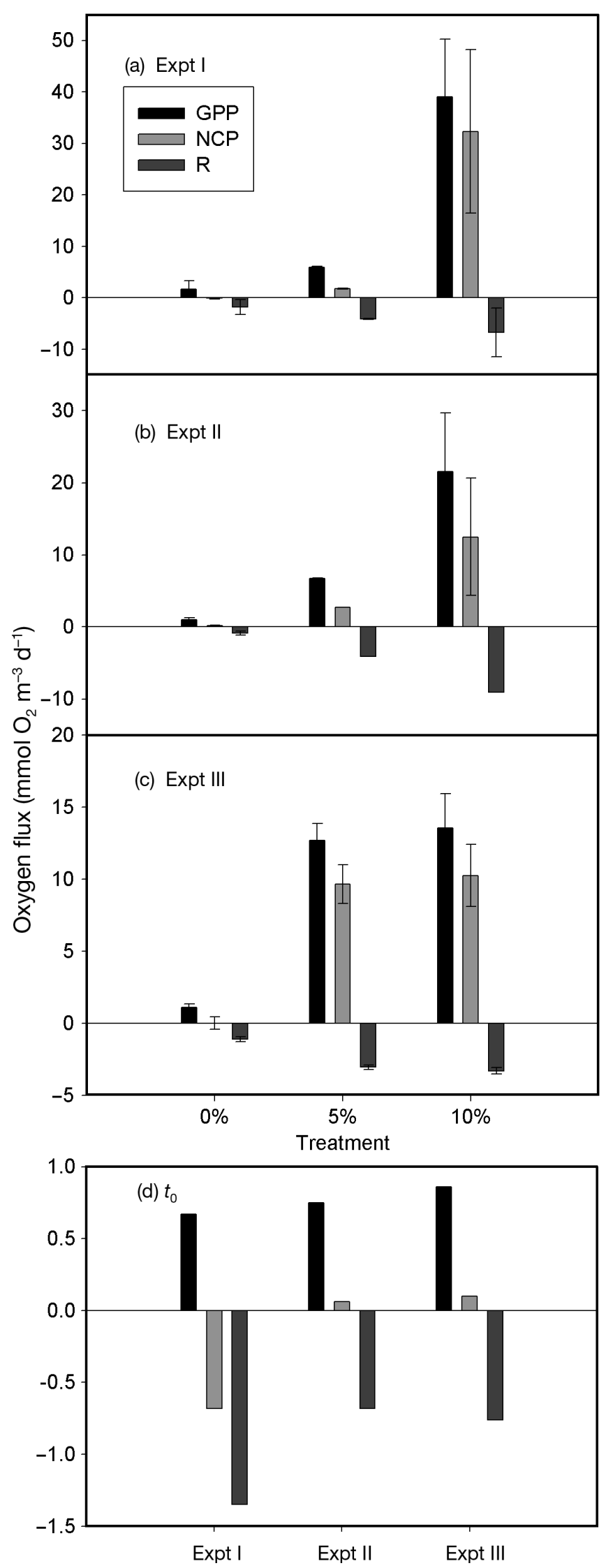

\section{Expt III}

The unamended treatment showed a decrease in chl a $\left(20 \%, \mu=-0.01 \mathrm{~d}^{-1}\right)$ and an increase in both GPP (1.3-fold) and R (1.4-fold); however, neither were statistically different from $t_{0}(\mathrm{p}=0.008$ and 0.003, respectively). Quantitative enumeration of cells by flow cytometry indicated little change in photosynthetic picoeukaryote and non-pigmented picoplankton abundances, whereas Synechococcus spp. cell abundance doubled and Prochlorococcus spp. abundance decreased by $70 \%$ during the experiment (Fig. 4). The $5 \%$ DSW treatment samples exhibited a $>10$-fold increase in both chl $a$ and $C$ (Fig. 2c,g; $\mu=0.62 \mathrm{~d}^{-1}$ ) and 15- and 4-fold increases in GPP and R, respectively (both were statistically different from $t_{0}$ and the unamended control, $\mathrm{p}=$ 0.008 and 0.003 , respectively). The GPP:R ratio increased from 1.1 to 4.2 , indicating sustained net autotrophic production throughout the experiment. Both non-pigmented picoplankton and Synechococcus abundances remained relatively constant; however, Prochlorococcus abundance decreased by $90 \%$ and photosynthetic picoeukaryote abundance increased 8-fold during the course of the experiment. Chl $a$ and $c$ increased 12- and 10-fold, respectively, in the $10 \%$ DSW treatment $\left(\mu=0.62 \mathrm{~d}^{-1}\right)$, while GPP and $\mathrm{R}$ increased 16- and 4.3-fold $(\mathrm{p}=0.008$ and 0.003), respectively, and the GPP: $R$ ratio increased from 1.1 to 4.1 (Tables $2 \& 3$ ). The average nonpigmented plankton cell abundance remained relatively constant, whereas Synechococcus and Prochlorococcus decreased 4 and $83 \%$, respectively. In contrast, photosynthetic picoeukaryote abundance increased by an approximate order of magnitude. The rate of drawdown of $\mathrm{PO}_{4}{ }^{3-}$ was approximately the same for both the 5 and $10 \%$ DSW treatments, and both were greater than the unamended treatment (Table 2).

Fig. 3. Primary production and respiration measured as oxygen at the end of (a) Expt I, (b) Expt II, and (c) Expt III. (d) Production and respiration at $t_{0}$. Gross primary production (GPP), net community production (NCP), and respiration (R) are shown. Note $y$-axis scale varies among panels. In (a) and (b), GPP of the $10 \%$ deep seawater (DSW) treatment differs statistically from that of the unamended control $(0 \%)$ and $5 \%$ DSW treatments; $p=0.027$ and 0.063 for (a) and (b), respectively. In (b), R of the 5 and $10 \%$ DSW treatments differs statistically from that of unamended control; $\mathrm{p}<0.0005$. In (c), GPP and R of the 5 and $10 \%$ DSW treatments differ statistically from those of the unamended control; $\mathrm{p}=0.008$ and 0.003 for GPP and R, respectively. Error bars are mean \pm SD 
Table 2. Response of chlorophyll and nutrient drawdown in experimental treatments. Concentrations of each pigment and nutrient at $t_{0}$ listed next to the rate of change $(\Delta)$ over the course of the experiment for each treatment. Chlorophyll concentra-

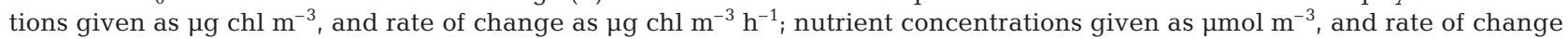
as $\mu \mathrm{mol} \mathrm{m} \mathrm{m}^{-3} \mathrm{~d}^{-1}$. ND: not detected

\begin{tabular}{|c|c|c|c|c|c|c|c|c|c|c|c|c|c|}
\hline Expt & Treatment & $\begin{array}{c}\text { Chl a } \\
t_{0}\end{array}$ & $\Delta \mathrm{Chl} \mathrm{a}$ & $\begin{array}{c}\text { Chl } b \\
t_{0}\end{array}$ & $\Delta \mathrm{Chl} b$ & $\begin{array}{c}\mathrm{Chl} c \\
t_{0}\end{array}$ & $\Delta \mathrm{Chl} c$ & $\begin{array}{c}\mathrm{N}+\mathrm{N} \\
t_{0}\end{array}$ & $\Delta N+N$ & $\begin{array}{c}\mathrm{PO}_{4}{ }^{3-} \\
t_{0}\end{array}$ & $\Delta \mathrm{PO}_{4}{ }^{3-}$ & $\begin{array}{c}\mathrm{SiO}_{2} \\
t_{0}\end{array}$ & $\Delta \mathrm{SiO}_{2}$ \\
\hline \multirow[t]{3}{*}{ I } & Control & $50 \pm 3$ & 2.1 & $63 \pm 16$ & -0.2 & $22 \pm 4$ & 0.8 & & & $75 \pm 17$ & -8 & & \\
\hline & $5 \%$ DSW & $94 \pm 11$ & 3.7 & $116 \pm 34$ & 0.6 & $38 \pm 17$ & 1.3 & & & $112 \pm 8$ & -11 & & \\
\hline & $10 \%$ DSW & $41 \pm 10$ & 2.9 & $42 \pm 7$ & 0.1 & $16 \pm 1$ & 1.0 & & & $418 \pm 222$ & $2-26$ & & \\
\hline \multirow[t]{3}{*}{ II } & Control & $43 \pm 2$ & 0.1 & $56 \pm 13$ & 0.8 & $21 \pm 3$ & 0.3 & $28 \pm 6$ & -1 & $24 \pm 4$ & -2 & ND & - \\
\hline & $5 \%$ DSW & $46 \pm 1$ & 8.2 & $35 \pm 13$ & 0.4 & $15 \pm 4$ & 1.7 & $1343 \pm 7$ & -322 & $123 \pm 5$ & -19 & $2639 \pm 81$ & -544 \\
\hline & $10 \%$ DSW & $39 \pm 0.2$ & 37.9 & $43 \pm 18$ & 0.7 & $16 \pm 3$ & 7.8 & $3239 \pm 33$ & -786 & $279 \pm 13$ & -49 & $6931 \pm 210$ & -1071 \\
\hline \multirow[t]{3}{*}{ III } & Control & $52 \pm 6$ & -0.2 & $46 \pm 18$ & -0.1 & $17 \pm 4$ & 0.0 & & & $115 \pm 1$ & -1 & & \\
\hline & $5 \%$ DSW & $46 \pm 1$ & 7.2 & $54 \pm 6$ & 0.0 & $19 \pm 5$ & 2.7 & & & $234 \pm 5$ & -16 & & \\
\hline & $10 \%$ DSW & $43 \pm 1$ & 5.1 & $51 \pm 13$ & -0.1 & $19 \pm 4$ & 1.9 & & & $342 \pm 4$ & -15 & & \\
\hline \multirow[t]{2}{*}{ IV } & Control & $104 \pm 5$ & 2.4 & $125 \pm 43$ & -2.9 & $22 \pm 2$ & 0.3 & $93 \pm 53$ & -8 & $86 \pm 9$ & -12 & $570 \pm 387$ & - \\
\hline & $5 \% \mathrm{DSW}$ & $81 \pm 12$ & 9.9 & $306 \pm 66$ & -0.1 & 28 & 0.9 & $2242 \pm 71$ & -58 & $257 \pm 9$ & -541 & $5409 \pm 247$ & -332 \\
\hline \multirow[t]{8}{*}{ V } & Control & & & & & & & & & $18 \pm 9$ & -2 & & \\
\hline & $0.2-2.0 \mu \mathrm{m}$ & 79 & -0.3 & 28 & $<0.1$ & 8 & $<0.1$ & & & & & & \\
\hline & $2-10 \mu \mathrm{m}$ & 27 & $<0.1$ & 25 & $<0.1$ & 6 & $<0.1$ & & & & & & \\
\hline & $>10 \mu \mathrm{m}$ & 200 & 0.4 & 28 & 0.3 & 5 & 0.1 & & & & & & \\
\hline & $5 \%$ DSW & & & & & & & & & $86 \pm 9$ & 4 & & \\
\hline & $0.2-2.0 \mu \mathrm{m}$ & 79 & 1.9 & 28 & $<0.1$ & 9 & 0.4 & & & & & & \\
\hline & $2-10 \mu \mathrm{m}$ & 26 & 0.2 & 60 & -0.4 & 10 & $<0.1$ & & & & & & \\
\hline & $>10 \mu \mathrm{m}$ & 202 & 22.2 & 35 & 1.0 & 7 & 0.2 & & & & & & \\
\hline
\end{tabular}

Table 3. Rates of production and respiration: initial $\left(t_{0}\right)$ and final $\left(t_{\mathrm{F}}\right)$ rates of carbon assimilation $\left({ }^{14} \mathrm{C}\right)$, gross primary production (GPP), net community production (NCP) and respiration (R) for each treatment for each experiment. The GPP:R ratio for $t_{0}$ and $t_{\mathrm{F}}$ calculated using the corresponding values of GPP and R. ${ }^{14} \mathrm{C}$ rates given as $\mathrm{mg} \mathrm{C} \mathrm{m}^{-3} \mathrm{~d}^{-1}$, and GPP, NCP and $\mathrm{R}$ as $\mathrm{mmol} \mathrm{O}_{2} \mathrm{~m}^{-3} \mathrm{~d}^{-1}$

\begin{tabular}{|c|c|c|c|c|c|c|c|c|c|c|c|}
\hline \multirow[t]{2}{*}{ Expt } & \multirow[t]{2}{*}{ Treatment } & \multicolumn{2}{|r|}{${ }^{14} \mathrm{C}$} & \multicolumn{2}{|r|}{$-\mathrm{GPP}=$} & \multicolumn{2}{|c|}{$-\mathrm{NCP}$} & \multicolumn{2}{|c|}{$-\mathrm{R}=$} & \multicolumn{2}{|c|}{ GPP:R } \\
\hline & & $t_{0}$ & $t_{\mathrm{F}}$ & $t_{0}$ & $t_{\mathrm{F}}$ & $t_{0}$ & $t_{\mathrm{F}}$ & $t_{0}$ & $t_{\mathrm{F}}$ & $t_{0}$ & $t_{\mathrm{F}}$ \\
\hline \multirow[t]{3}{*}{ I } & Control & $8.31 \pm 3.04$ & $25.11 \pm 20.88$ & 0.67 & $1.72 \pm 1.58$ & -0.68 & $-0.09 \pm 0.16$ & 1.35 & $1.81 \pm 1.41$ & 0.50 & 0.87 \\
\hline & $5 \%$ DSW & & $82.20 \pm 44.65$ & & $5.92 \pm 0.21$ & & $1.78 \pm 0.12$ & & $4.14 \pm 0.08$ & & 1.43 \\
\hline & $10 \%$ DSW & & $397.11 \pm 35.17$ & & $39.03 \pm 11.18$ & & $32.33 \pm 15.91$ & & $6.70 \pm 4.72$ & & 8.53 \\
\hline \multirow[t]{3}{*}{ II } & Control & $3.63 \pm 1.46$ & $5.72 \pm 0.67$ & 0.75 & $1.03 \pm 0.22$ & 0.06 & $0.18 \pm 0.06$ & 0.68 & $0.85 \pm 0.28$ & 1.10 & 1.23 \\
\hline & $5 \% \mathrm{DSW}$ & & $76.33 \pm 35.24$ & & $6.73 \pm 0.07$ & & $2.72 \pm 0.03$ & & $4.10 \pm 0.03$ & & 1.64 \\
\hline & $10 \%$ DSW & & $169.40 \pm 30.97$ & & $21.56 \pm 8.16$ & & $12.49 \pm 8.14$ & & $9.08 \pm 0.01$ & & 2.37 \\
\hline \multirow[t]{3}{*}{ III } & Control & $3.85 \pm 1.12$ & $7.07 \pm 0.66$ & 0.86 & $1.12 \pm 0.23$ & 0.10 & $0.03 \pm 0.42$ & 0.76 & $1.09 \pm 0.18$ & 1.13 & 1.06 \\
\hline & $5 \% \mathrm{DSW}$ & & $48.97 \pm 4.41$ & & $12.70 \pm 1.18$ & & $9.67 \pm 1.34$ & & $3.03 \pm 0.16$ & & 4.21 \\
\hline & $10 \%$ DSW & & $58.84 \pm 7.26$ & & $13.56 \pm 2.38$ & & $10.27 \pm 2.14$ & & $3.30 \pm 0.23$ & & 4.10 \\
\hline \multirow[t]{2}{*}{ IV } & Control & $8.91 \pm 0.03$ & $24.52 \pm 7.10$ & & & & & & & & \\
\hline & $5 \%$ DSW & $13.29 \pm 7.63$ & $136.16 \pm 14.53$ & & & & & & & & \\
\hline \multirow[t]{8}{*}{ V } & Control & & & & & & & & & & \\
\hline & $0.2-2.0 \mu \mathrm{m}$ & $1.51 \pm 0.77$ & $0.74 \pm 0.33$ & & & & & & & & \\
\hline & $2-10 \mu \mathrm{m}$ & $0.02 \pm 0.01$ & $0.07 \pm 0.03$ & & & & & & & & \\
\hline & $>10 \mu \mathrm{m}$ & $2.35 \pm 0.33$ & $4.63 \pm 0.14$ & & & & & & & & \\
\hline & $5 \%$ DSW & & & & & & & & & & \\
\hline & $0.2-2.0 \mu \mathrm{m}$ & $1.69 \pm 0.12$ & $2.89 \pm 0.79$ & & & & & & & & \\
\hline & $2-10 \mu \mathrm{m}$ & $0.03 \pm 0.01$ & $1.21 \pm 0.77$ & & & & & & & & \\
\hline & $>10 \mu \mathrm{m}$ & $2.92 \pm 0.06$ & $31.71 \pm 4.77$ & & & & & & & & \\
\hline
\end{tabular}




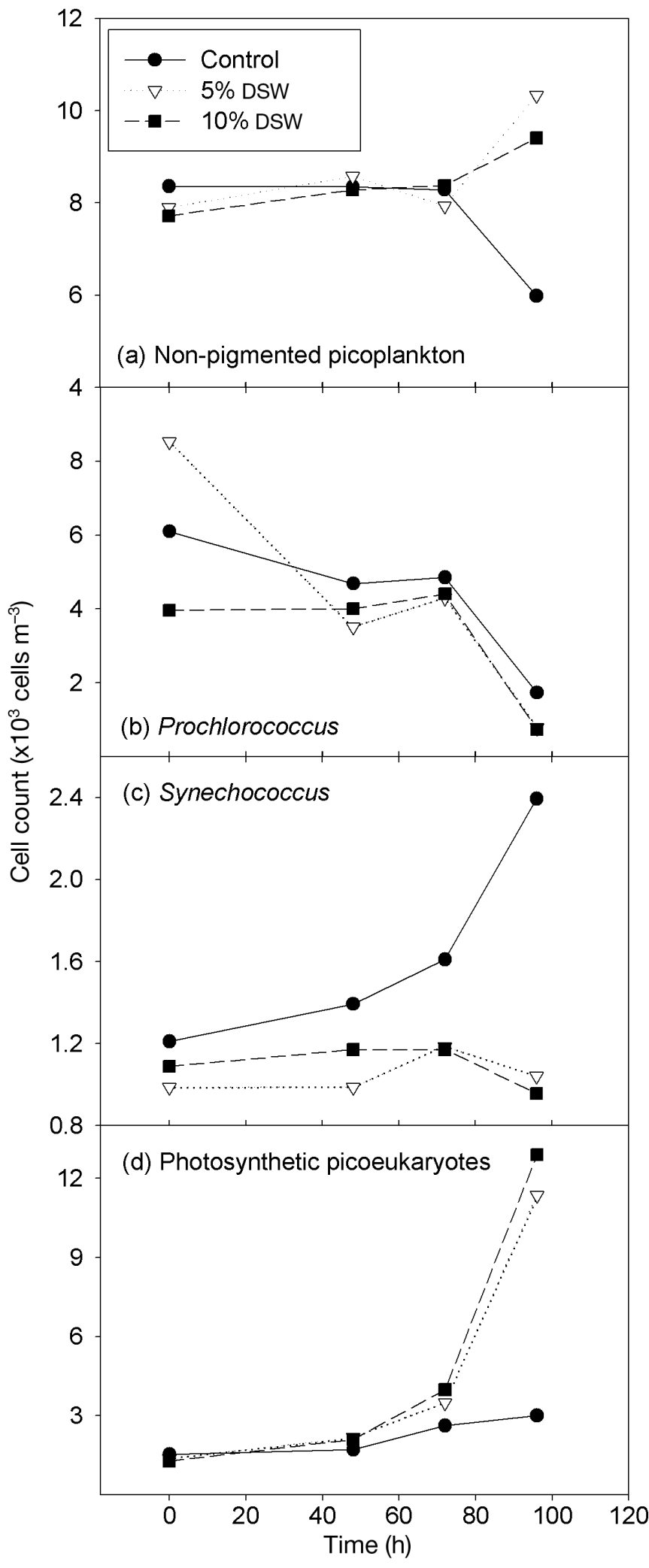

Fig. 4. Expt III: cell abundances of (a) non-pigmented picoplankton, (b) Prochlorococcus spp., (c) Synechococcus spp., and (d) photosynthetic picoeukaryotes. Unamended control and additions of 5 and $10 \%$ DSW are shown

\section{Expt IV}

Chl $a$ and $c$ concentrations in the unamended treatment increased 4- and 3-fold, respectively, after $60 \mathrm{~h}$ $\left(\mu=0.15 \mathrm{~d}^{-1}\right.$; Fig. $\left.2 \mathrm{~d}, \mathrm{~h}\right)$, and primary production as measured by ${ }^{14} \mathrm{C}$-assimilation increased nearly 3 -fold (Tables $2 \& 3$ ). In the $5 \%$ DSW treatment chl $a$ and $C$ increased 10- and 6-fold, respectively, throughout the experiment $\left(\mu=0.42 \mathrm{~d}^{-1}\right)$, and primary production increased 10 -fold from $2.2 \mathrm{mmol} \mathrm{C} \mathrm{m} \mathrm{C}^{-3} \mathrm{~d}^{-1}$ at $t_{0}$ to $22.7 \mathrm{mmol} \mathrm{C} \mathrm{m}{ }^{-3} \mathrm{~d}^{-1}$ after $96 \mathrm{~h}$ incubation. Nutrient drawdown rates were greater for the $5 \%$ DSW treatment than for the unamended treatment.

\section{Expt V}

The purpose of this experiment was to determine whether nutrient amendment altered cell size or carbon production by selected plankton size classes. In the unamended treatment chl a remained the same or decreased slightly in all size fractions, whereas chl $C$ increased $(9 \%, 40 \%$ and 3 -fold in the 0.2 to $2.0,2.0$ to 10 and $>10 \mu \mathrm{m}$ size fractions, respectively; Fig. 5). ${ }^{14} \mathrm{C}$-bicarbonate assimilation decreased in the 0.2 to $2.0 \mu \mathrm{m}$ size fraction and increased in the 2.0 to 10 and $>10 \mu \mathrm{m}$ size fractions (4- and 2-fold, respectively). In the 5\% DSW treatment, chl a increased 3.3-, 1.6- and 11.5 -fold in the 0.2 to $2.0,2.0$ to 10 and $>10 \mu \mathrm{m}$ size fractions, respectively, and chl $c$ increased 5.3- and 3.2-fold in the 0.2 to 2.0 and $>10 \mu \mathrm{m}$ size fractions, respectively. In the 2.0 to $10 \mu \mathrm{m}$ size fraction, chl $c$ showed high variability and a net decrease by the end of the experiment. ${ }^{14} \mathrm{C}$-bicarbonate assimilation by the 0.2 to $2.0 \mu \mathrm{m}$ size fraction increased $70 \%$ over the course of the experiment, and dramatic increases of 49- and 11-fold were observed in the 2.0 to 10 and $>10 \mu \mathrm{m}$ size fractions, respectively (Fig. 6). The rate of drawdown of $\mathrm{PO}_{4}{ }^{3-}$ was greater in the unamended treatment than in the $5 \%$ DSW treatment (Table 2).

\section{DISCUSSION}

Several consistent and predictable features were observed following the addition of nutrient-replete deep-ocean water to oligotrophic upper ocean water, including: (1) an increase in both chl $a$ and primary production, as determined by $\mathrm{O}_{2}$ fluxes and ${ }^{14} \mathrm{C}$ assimilation; (2) an apparent shift in the photoautotrophic assemblage size structure towards large, chl c-containing plankton, presumably diatoms; and (3) a shift in the metabolic balance from a nutrient-limited system poised at or near the GPP $=\mathrm{R}$ balance point to $\mathrm{a}$ demonstrably net autotrophic (GPP $>$ R) system. 


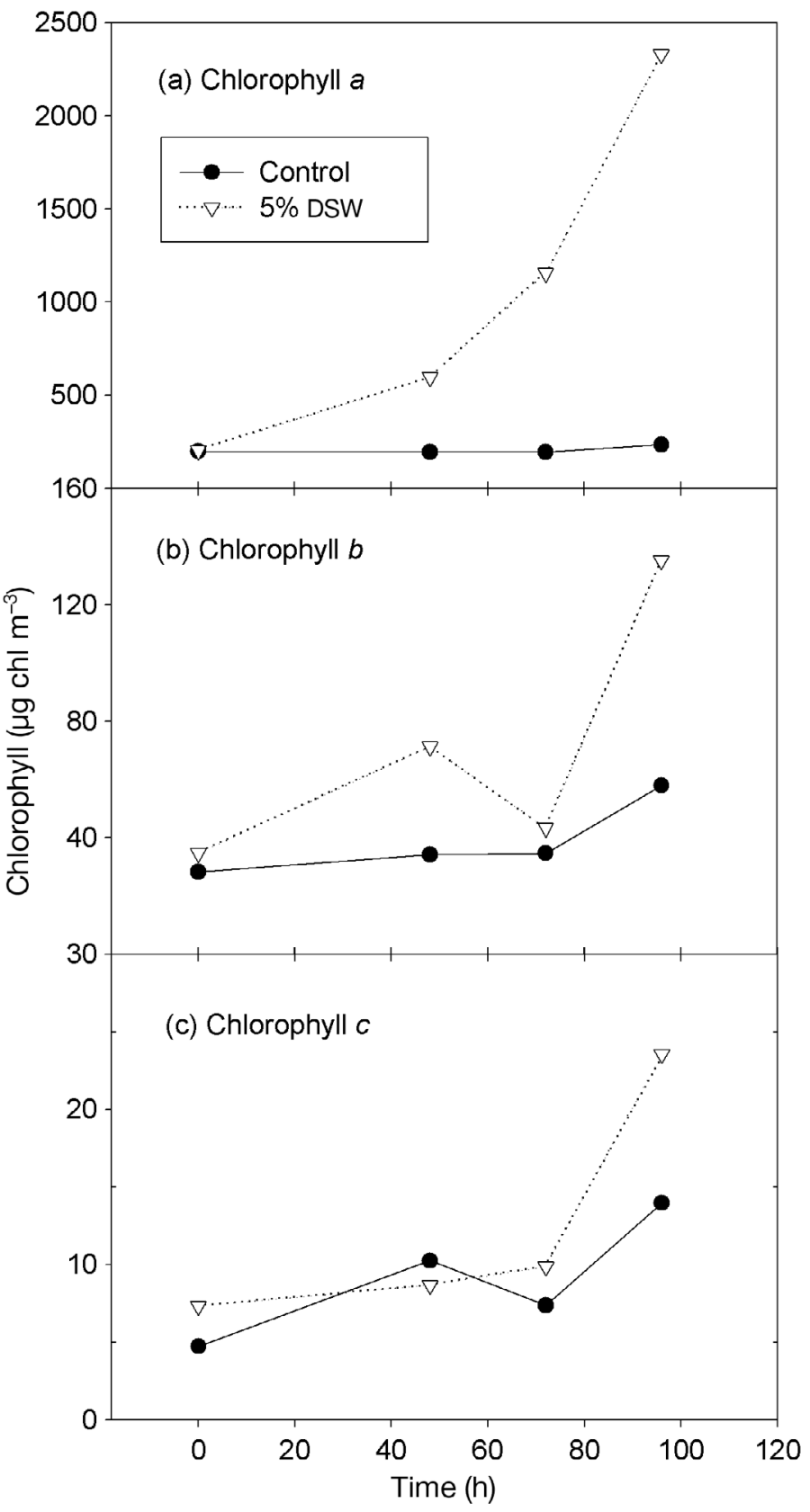

Fig. 5. Expt $\mathrm{V}_{1}>10 \mu \mathrm{m}$ size fraction: (a) chl $a$, (b) chl $b$, and (c) chl c. Unamended control and additions of 5 and $10 \%$ DSW are shown. Note $y$-axis scale varies among panels

\section{Rates of production and respiration}

Increases in production occurred on time scales shorter than $1 \mathrm{wk}$, indicating that it is possible to rapidly increase GPP over short time scales in oligotrophic ocean waters following the addition of nutrients. In contrast, the magnitude of the response in $\mathrm{R}$ was significantly lower than the response in GPP for the same time period ( 3 to $4 \mathrm{~d}$ ). Thus, nutrient addi-

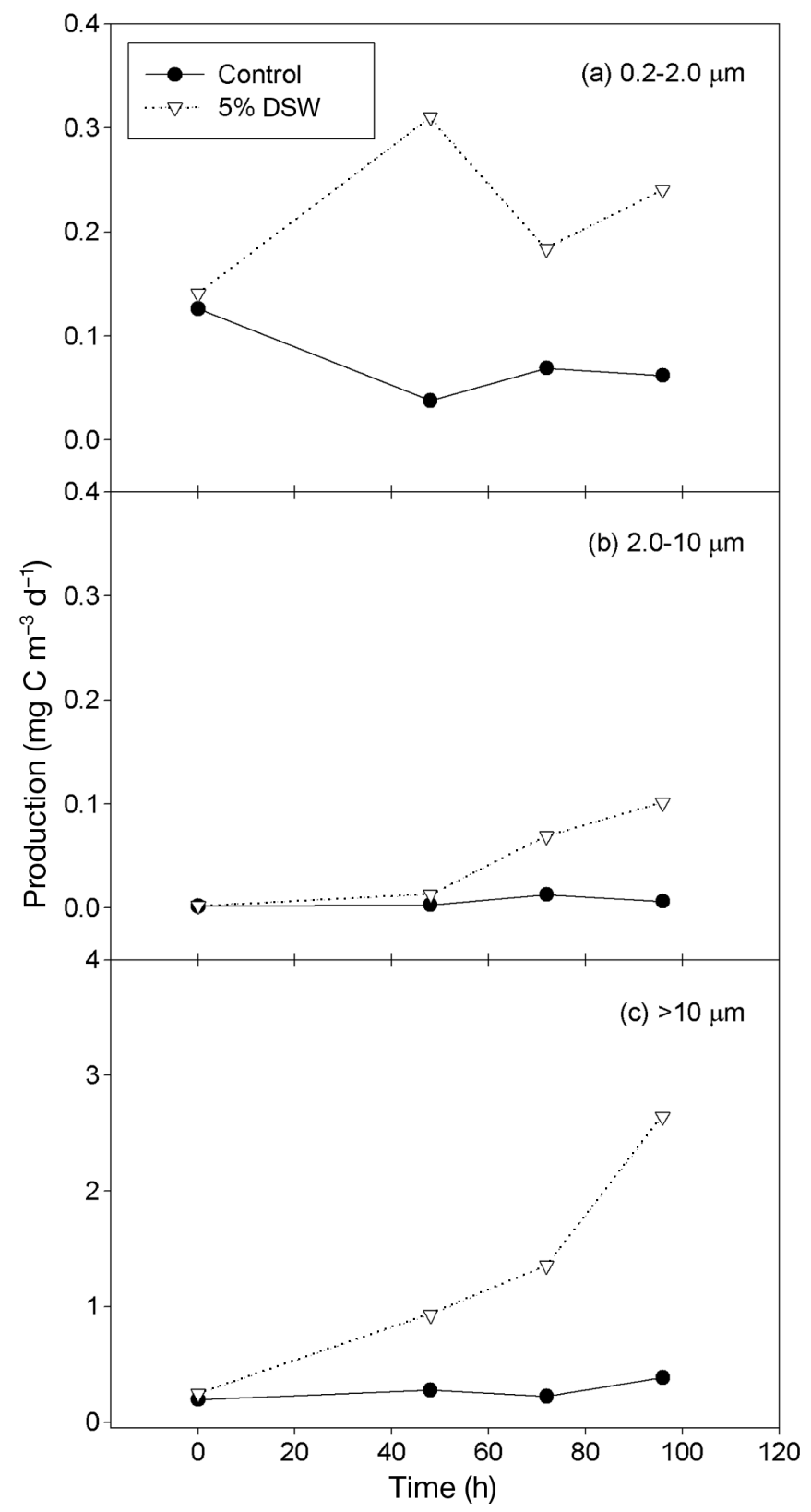

Fig. 6. Expt V, primary production rates of size fractions: (a) $0.2-2.0 \mu \mathrm{m}$, (b) $2.0-10 \mu \mathrm{m}$, and (c) $>10 \mu \mathrm{m}$. Unamended control and additions of 5 and $10 \%$ DSW are shown. Note $y$-axis scale varies among panels

tions to these oligotrophic waters consistently shifted the metabolic state of these experiments from net heterotrophy, or approximately balanced system metabolism, to net autotrophy. Control treatments maintained relatively constant rates of production and respiration during the course of the experiments, indicating that blooms observed after nutrient addition were not an artifact of containment inside incubation bottles. 
In 3 of the 5 experiments, we examined the metabolic response of upper ocean plankton assemblages to variable amounts of nutrient-rich DSW. Interestingly, rates of GPP and $\mathrm{R}$ did not increase in proportion to the amount of nutrient added. Expt I yielded $\mathrm{O}_{2}$ fluxes of $\sim 6$ and $\sim 40 \mathrm{mmol} \mathrm{O}_{2} \mathrm{~m}^{-3} \mathrm{~d}^{-1}$ for 5 and 10\% DSW treatments, respectively. If the response in GPP scaled linearly with the amount of added nutrients, GPP in the $10 \%$ nutrient addition would have been nearly 4 -fold lower $\left(12 \mathrm{mmol} \mathrm{O}_{2} \mathrm{~m}^{-3} \mathrm{~d}^{-1}\right)$ than what was measured. This observation suggests there may be a minimum threshold concentration of nutrients required to elicit the observed metabolic changes. Alternatively, the plankton assemblages may have responded in a nonlinear manner to nutrient input, or scaling of the response to nutrient concentration may require integration over longer time scales.

The initial community composition of the plankton assemblage also likely affected the outcome of these experiments. The rate of chlorophyll accumulation in each experiment varied after nutrient addition, suggesting that the types of plankton and degree of trophodynamic coupling at the beginning of each experiment could have varied among these experiments, thereby influencing rates of chlorophyll accumulation, nutrient drawdown and response of GPP and R among experiments. For example, Expt I had greater rates of GPP at the end of the experiment than Expt III.

A $5 \%$ addition of $700 \mathrm{~m}$ DSW adds approximately $1.5 \mathrm{mmol} \mathrm{m}^{-3} \mathrm{~N}+\mathrm{N}$ and $0.1 \mathrm{mmol} \mathrm{m}^{-3} \mathrm{PO}_{4}{ }^{3-}$ to the nutrient-deprived MLSW at Stn ALOHA, and a 10\% addition adds twice those concentrations. Fig. 7 shows the time series of average $\mathrm{N}+\mathrm{N}$ and $\mathrm{PO}_{4}{ }^{3-}$ concentrations calculated from integrated concentrations between 0 and $50 \mathrm{~m}$ at Stn ALOHA. Although we observed phosphate concentrations at Stn ALOHA near those achieved in the $5 \%$ addition experiments, we did not observe corresponding high $\mathrm{N}+\mathrm{N}$ concentrations. The rapid coupling of growth and nutrient removal demonstrated in the present study likely precludes substantial accumulation of nutrients in the euphotic zone, making it difficult to capture a high nutrient event with a monthly sampling regime.

\section{GPP:R ratio}

In our experiments, deviation from unity in the GPP:R ratio indicates temporal decoupling of GPP from R. Comparison of ratios from the first and last days of the experiments revealed that decoupling occurred after the addition of nutrients in all experiments. Replicate control treatments maintained a GPP:R ratio of $\sim 1$ or slightly less than 1 throughout the experiment, whereas the $10 \%$ nutrient addition increased this ratio
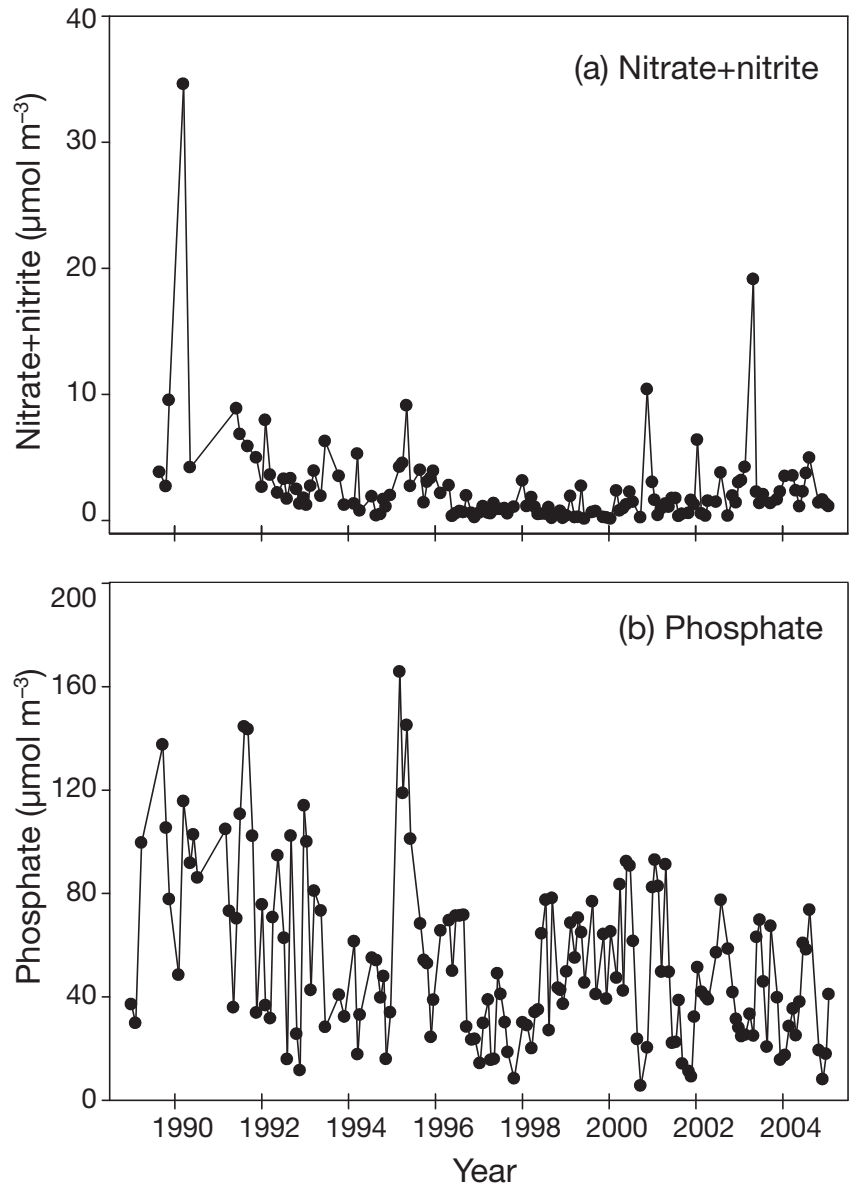

Fig. 7. Stn ALOHA: concentration climatology of (a) nitrate+ nitrite $(\mathrm{N}+\mathrm{N})$, and (b) phosphate $\left(\mathrm{PO}_{4}{ }^{3-}\right)$. Average concentrations of $\mathrm{N}+\mathrm{N}$ and $\mathrm{PO}_{4}{ }^{3-}$ between 0 and $50 \mathrm{~m}$ plotted over time. Observed magnitude of nutrient input at Stn ALOHA is similar to nutrient concentrations added in our experimental manipulations

4- to 20-fold. These results indicate that rates of GPP increased faster than rates of $\mathrm{R}$ following nutrient addition. The result is an increase in NCP and a shift in community metabolism from net heterotrophy to net autotrophy.

Similar to rates of production, the GPP:R ratios did not increase predictably with increasing nutrient perturbation. In Expt I, the ratio increased approximately 4 -fold between the 5 and $10 \%$ additions, whereas in Expt II, the GPP:R ratio varied by less than a factor of two over the course of the experiment. Expt III showed similar increases in rates of production between the 5 and $10 \%$ additions, suggesting that factors other than the magnitude of nutrient addition influence community response to nutrient inputs. The composition of the initial plankton assemblage (including the coupled relationships of predators and prey) likely determined the magnitude of biomass accumulation and coincident nutrient drawdown in these experiments. 


\section{Plankton community structure and dynamics}

Based on the 17 yr data set from Stn ALOHA, the chl a-containing plankton community is dominated by Prochlorococcus spp., which also contains chl $b$, with negligible contributions from diatoms that also contain chl $C$ (Letelier et al. 1993). After the addition of nutrients, chl $a$ and $c$ increased exponentially, whereas chl $b$ generally decreased. Large increases in chl $a$ and $c$ were observed in the larger plankton size fractions. For example, cell counts from Expt III indicated a significant increase (approximately 1 order of magnitude) in photosynthetic picoeukaryotes ( $\sim 2$ to $20 \mu \mathrm{m}$ diameter). Similarly, size-fractionated chlorophyll samples from Expt $\mathrm{V}$ confirmed that the growth of the larger size class of plankton $(>10 \mu \mathrm{m})$ was selectively stimulated by the addition of nutrients.

The phenomenon whereby large phytoplankton are selectively stimulated by nutrient injection events has been previously studied and modeled by Goldman (1993), who showed that phytoplankton larger than $50 \mu \mathrm{m}$ in size contributed disproportionately to new production in the euphotic zone after nutrient addition. In the $>10 \mu \mathrm{m}$ size fraction of Expt V, chl a increased by a factor of 10 while chl $C$ increased 5- to 10-fold. Size-fractionated primary production measurements from the same experiment indicate a 10 -fold increase in $\mathrm{C}$ assimilation by the $>10 \mu \mathrm{m}$ size fraction throughout the course of the experiment.

Diatoms appear at least partially responsible for the observed increase in $\mathrm{chl} c$ in the $>10 \mu \mathrm{m}$ size fraction. This conclusion is supported, in part, by net changes in $\mathrm{N}+\mathrm{N}: \mathrm{SiO}_{2}$ drawdown ratios. In a system where diatoms are dominant, the $\mathrm{N}+\mathrm{N}: \mathrm{SiO}_{2}$ uptake ratio should approach unity (Brzezinski 1985). In Expt II, the $\mathrm{N}+\mathrm{N}: \mathrm{SiO}_{2}$ drawdown ratio approached unity as the amount of nutrient added increased (0.59 and 0.73, for 5 and $10 \%$ additions, respectively). Silica drawdown was greater than nitrate drawdown after the addition of nutrients, suggesting that diatom growth may have been limited by nitrogen rather than by silica (Harrison et al. 1976, 1977).

The unamended controls from Expts I to IV showed increases in chl a concentration (average $\mu=$ $0.09 \mathrm{~d}^{-1}$ ) despite no nutrient addition. If our experimental design excluded predators and altered the trophic dynamics in the water sample, this would presumably influence the net growth rate of controls and nutrient-amended treatments alike. This could account for the observed increase in growth rate in controls. In all experiments, the addition of nutrients significantly increased net growth above that of controls $(p=0.001)$.

\section{Metabolic balance}

It has been hypothesized (Karl et al. 2003, Williams et al. 2004) that metabolic balance in the open ocean is maintained by aperiodic, large magnitude net autotrophic events and that frequent, if not continuous, sampling is necessary to obtain an accurate estimate of the seasonal and annual net metabolism of the open ocean. Our perturbation experiments clearly documented shifts from GPP $\approx \mathrm{R}$ to GPP $\gg \mathrm{R}$, following the addition of nutrient-rich waters. Moreover, our results suggest that nutrient additions can cause large alterations in the net metabolic balance of oligotrophic surface waters on relatively short $(<1 \mathrm{wk})$ time scales.

In a system in which intermittent net autotrophic events fuel a more constant state of net heterotrophy, the probability of observing the system in a net heterotrophic metabolic state would be much greater than observing it in a net autotrophic state. We demonstrated that autotrophic events can be large in magnitude but short in duration. Therefore, to understand the metabolic balance of a system, it is important to know the magnitude and duration of net autotrophic events in order to calculate how long a period of net heterotrophic metabolism can be supported. The probability of incorrectly characterizing the metabolic state of a system as a result of using in vitro techniques was discussed by Karl et al. (2003). These authors also noted that it is difficult to determine the magnitude and duration of net autotrophic events even with a monthly sampling scheme, such as the HOT program follows, as sampling is too infrequent.

Short-term (daily time scale) bursts of photosynthetic production reflect non steady-state processes initiated by alterations in bottom-up or top-down plankton processes. Such alterations could include introduction of a limiting nutrient or nutrients (either from below the mixed-layer or by atmospheric deposition); temporal variations in the relationships between predators (including viruses) and their prey; or by physical forcing of key habitat parameters (e.g. variations in light). Of these, episodic delivery of inorganic nutrients to the mixed-layer of low nutrient systems partly explains high frequency variations in photosynthetic production (Aristegui \& Harrison 2002). Nutrient input to the euphotic zone could result from any of a number of possible mesoscale phenomena including internal waves (Garrett 2003, Gregg et al. 2003), eddies (Falkowski et al. 1991, McGillicuddy et al. 1998, 1999, Gonzalez et al. 2001, Seki et al. 2001), subtropical fronts (Gonzalez et al. 2001) or Rossby waves (Uz et al. 2001, Sakamoto et al. 2004).

Our experiments revealed that photosynthesis and respiration can be temporally decoupled through nutrient enrichment. In addition, our results provided 
indications of the time scales of potential responses to periodic, bottom-up ecosystem forcing at Stn ALOHA. To fully understand how such processes alter ecosystem metabolism, it is essential to quantify the rate of decoupling between auto- and heterotrophic processes. Our results indicated that over short time scales ( 3 to $4 \mathrm{~d}$ ), the response of $\mathrm{R}$ is slower than that of GPP.

Further research will be necessary to fully examine the question of metabolic balance in the open ocean and how temporal decoupling of metabolic processes may bias our measurement of NCP. In particular, determination of how plankton community composition (including the size spectrum of plankton assemblages) responds to nutrient perturbations will be essential to establishing how important nutrient enrichment events are to open ocean ecosystem metabolism. The decoupling of photosynthesis and respiration by nutrient availability could provide one mechanism for apparent imbalances in GPP and R in oligotrophic ecosystems; however, it is unlikely that such bottom-up forcings are the sole basis for the observed imbalances.

Acknowledgements. We thank the HOT program staff and A. Shea for their assistance with analysis of samples, and the captain and crew of RVs 'Revelle' and 'Kaimikai-O-Kanaloa'. We also thank the US National Science Foundation (OCE 0326616 and OCE 99-81313) and the Gordon and Betty Moore Foundation for funding, and C. Duarte and 2 anonymous reviewers for comments on the manuscript.

\section{LITERATURE CITED}

Abell J, Emerson S, Renaud P (2000) Distributions of TOP, TON and TOC in the North Pacific Subtropical Gyre: implications for nutrient supply in the surface ocean and remineralization in the upper thermocline. J Mar Res 58: 203-222

Aristegui J, Harrison WJ (2002) Decoupling of primary production and community respiration in the ocean: implications for regional carbon studies. Aquat Microb Ecol 29: 199-209

Armstrong FA, Sterns CR, Strickland JSH (1967) The measurement of upwelling and subsequent biological processes by means of the Technicon Autoanalyzer and associated equipment. Deep-Sea Res 14:381-389

Behrenfeld MJ, Esaias WE, Turpie KR (2002) Assessment of primary productivity at the global scale. In: Reynolds CS (ed) Phytoplankton productivity: carbon assimilation in marine and freshwater systems. Blackwell Scientific Publishers, London, p 156-186

Brzezinski MA (1985) The Si:C:N ratio of marine diatoms: interspecific variability and the effect of some environmental variables. J Phycol 21:347-357

Campbell L, Vaulot D (1993) Photosynthetic picoplankton community structure in the subtropical North Pacific Ocean near Hawaii (Station ALOHA). Deep-Sea Res I 40: 2043-2060

Campbell L, Nolla HA, Vaulot D (1994) The importance of Prochlorococcus to community structure in the central North Pacific Ocean. Limnol Oceanogr 39:954-961
Carritt DE, Carpenter JH (1966) Comparison and evaluation of currently employed modifications of the Winkler method for determining dissolved oxygen in seawater; A NASCO report. J Mar Res 24:286-318

Church MJ, Ducklow HW, Karl DM (2002) Multiyear increases in dissolved organic matter inventories at Station ALOHA in the North Pacific Subtropical Gyre. Limnol Oceanogr 47:1-10

Dachs J, Calleja M, Duarte C, del Vento S, Turpin B, Polidori A, Herndl G, Agusti S (2005) High atmosphere-ocean exchange of organic carbon in the NE subtropical Atlantic. Geophys Res Lett 32:L21807, doi:10.1029/2005GL023799

del Giorgio PA, Duarte CM (2002) Respiration in the open ocean. Nature 420:379-384

del Giorgio PA, Cole JJ, Cimbleris A (1997) Respiration rates in bacteria exceed phytoplankton production in unproductive aquatic systems. Nature 385:148-151

Duarte CM, Agusti S (1998) The $\mathrm{CO}_{2}$ balance of unproductive aquatic ecosystems. Science 281:234-236

Emerson S, Quay PD, Stump C, Wilbur D, Schudlich R (1995) Chemical tracers of productivity and respiration in the subtropical Pacific Ocean. J Geophys Res 100: 15873-15887

Emerson S, Stump C, Johnson B, Karl DM (2002) In situ determination of oxygen and nitrogen dynamics in the upper ocean. Deep-Sea Res I 49:941-952

Falkowski PG, Ziemann D, Kolber Z, Bienfang PK (1991) Role of eddy pumping in enhancing primary production in the ocean. Nature 352:55-58

Garrett C (2003) Mixing with latitude. Nature 422:477-478

Goldman JC (1993) Potential role of large oceanic diatoms in new primary production. Deep-Sea Res I 40:159-168

Gonzalez N, Anadon R, Mourino B, Fernandez E, Sinha B, Escanez J, Armas DD (2001) The metabolic balance of the planktonic community in the North Atlantic subtropical gyre: the role of mesoscale instabilities. Limnol Oceanogr 46:946-952

Gregg MC, Sanford TB, Winkel DP (2003) Reduced mixing from the breaking of internal waves in equatorial waters. Nature 422:513-515

Hansell DA, Bates NR, Carlson CA (1997) Predominance of vertical loss of carbon from surface waters of the equatorial Pacific Ocean. Nature 386:59-61

Harrison PJ, Conway HL, Dugdale RC (1976) Marine diatoms grown in chemostats under silicate or ammonium limitation. I. Cellular chemical composition and steady state growth kinetics of Skeletonema costatum. Mar Biol 35: 177-86

Harrison PJ, Conway HL, Davis CO (1977) Marine diatoms grown in chemostats under silicate or ammonium limitations. III. Cellular chemical composition and morphology of Chaetoceros deblis, Skeletonema costatum, and Thalassiosira gravida. Mar Biol 43:19-31

Holm-Hansen O, Lorenzen CJ, Holmes RW, Strickland JDH (1965) Fluorometric determination of chlorophyll. J Cons 30:3-15

Juranek L, Quay P (2005) In vitro and in situ gross primary and net community production in the North Pacific Subtropical Gyre using labeled and natural abundance isotopes of dissolved $\mathrm{O}_{2}$. Global Biogeochem Cycles 19: GB3009, doi:10.1029/2004GB002384

Karl DM, Lukas R (1996) The Hawaii Ocean Time-series (HOT) program: background, rationale and field implementation. Deep-Sea Res II 43:129-156

Karl DM, Tien G (1992) MAGIC: a sensitive and precise method for measuring dissolved phosphorus in aquatic environments. Limnol Oceanogr 37:105-116 
Karl DM, Hebel D, Bjorkman K, Letelier R (1998) The role of dissolved organic matter release in the productivity of the oligotrophic North Pacific Ocean. Limnol Oceanogr 43: 1270-1286

Karl DM, Laws EA, Morris P, Williams PJleB, Emerson S (2003) Metabolic balance of the open sea. Nature 426:32

Letelier RM, Bidigare RR, Hebel DV, Ondrusek M, Winn CD, Karl DM (1993) Temporal variability of phytoplankton community structure based on pigment analysis. Limnol Oceanogr 38:1420-1437

Letelier RM, Dore JE, Winn CD, Karl DM (1996) Seasonal and interannual variations in photosynthetic carbon assimilation at Station ALOHA. Deep-Sea Res II 43:467-490

Marra J (1978) Phytoplankton photosynthetic response to vertical movement in a mixed layer. Mar Biol 46:203-208

Marra J (2002) Approaches to the measurement of plankton production. In: Reynolds CS (ed) Phytoplankton productivity: carbon assimilation in marine and freshwater ecosystems. Blackwell Scientific, Cambridge, p 78-108

McGillicuddy DJ, Robinson AR, Siegel DA, Jannasch HW and 5 others (1998) Influence of mesoscale eddies on new production in the Sargasso Sea. Nature 394:263-266

McGillicuddy DJ, Johnson R, Siegel DA, Michaels AF, Bates NR, Knap AH (1999) Mesoscale variations of biogeochemical properties in the Sargasso Sea. J Geophys Res 104:13381-13394

Monger BC, Landry MR (1993) Flow cytometric analysis of marine bacteria with Hoechst 33342. Appl Environ Microbiol 59:905-911

Najjar RG, Keeling RF (2000) Mean annual cycle of the air-sea oxygen flux: a global view. Global Biogeochem Cycles 14: 573-584

Sakamoto CM, Karl DM, Jannasch HW, Bidigare RR and 5 others (2004) Influence of Rossby waves on nutrient dynamics and the plankton community structure in the North Pacific Subtropical Gyre. J Geophys Res 109: C05032, doi:10.1029/2003JC001976

Editorial responsibility: Barry and Evelyn Sherr (Contributing Editors), Corvallis, Oregon, USA
Seki MP, Polovina JJ, Brainard RE, Bidigare RR, Leonard CL, Foley DG (2001) Biological enhancement at cyclonic eddies tracked with GOES thermal imagery in Hawaiian waters. Geophys Res Lett 28:1583-1586

Serret P, Fernandez E, Sostres J, Anadon R (1999) Seasonal compensation of microbial production and respiration in a temperate sea. Mar Ecol Prog Ser 187:43-57

Serret P, Fernandez E, Robinson C (2002) Biogeographic differences in the net ecosystem metabolism of the open ocean. Ecology 83:3225-3234

Sherr EB, Sherr BF (1996) Temporal offset in oceanic production and respiration processes implied by seasonal changes in atmospheric oxygen: the role of heterotrophic microbes. Aquat Microb Ecol 11:91-100

Smith KL, Baldwin RJ, Karl DM, Boetius A (2002) Benthic community responses to pulses in pelagic food supply: North Pacific Subtropical Gyre. Deep-Sea Res I 49:971-990

Smith SV, Mackenzie FT (1987) The ocean as a net heterotrophic system: implications from the carbon biogeochemical cycle. Global Biogeochem Cycles 1:187-198

Strickland JDH, Parsons TR (1972) A practical handbook of seawater analysis. Fisheries Research Board of Canada, Ottawa

Uz BM, Yoder JA, Osychny V (2001) Pumping of nutrients to ocean surface waters by the action of propagating planetary waves. Nature 409:597-600

Welschmeyer NA (1994) Fluorometric analysis of chlorophyll $\mathrm{a}$ in the presence of chlorophyll $\mathrm{b}$ and pheopigments. Limnol Oceanogr 39:1985-1992

Williams PJleB, Bowers DG (1999) Regional carbon imbalances in the oceans. Science 284:173-174

Williams PJleB, Jenkinson NW (1982) A transportable microprocessor-controlled precise Winkler titration suitable for field station and shipboard use. Limnol Oceanogr 27: 576-584

Williams PJleB, Morris PJ, Karl DM (2004) Net community production and metabolic balance at the oligotrophic ocean site, Station ALOHA. Deep-Sea Res I 51:1563-1578

Submitted: December 12, 2005; Accepted: July 31, 2006

Proofs received from author(s): February 21, 2007 